\title{
A KORAGYERMEKKORI NEVELÉS CURRICULUMÁNAK FOGADTATÁSA AZ ÓVODAPEDAGÓGUSOK KÖRÉBEN
}

\section{THE RECEPTION OF THE CURRICULUM OF EARLY CHILDHOOD EDUCATION TO TEACHERS}

\author{
Stark Gabriella
}

\begin{abstract}
The study focuses on the reception of the 2019 curriculum of early childhood education by teachers. The goal of this paper is to present how teachers relate to the change and curriculum implementation of it. The research method was a survey; the sample consists of minority Hungarians preschool teachers $(\mathrm{N}=118)$. The results of the online survey are presented along the following focus points: associations related to the curriculum, the need for curriculum change, satisfaction and readiness among teachers, ways of implementing the curriculum, personal attitudes towards the curriculum. In the curriculum associations of teachers, child-centeredness and competence appeared the most, as well as freedom, change, development, experimentation and complexity. I concluded that the teachers learned about the curriculum mainly through autonomous learning. The main factors influencing the curriculum implementation are the professional experience of the teacher and the type of kindergarten. Based on the factor analysis, the teachers can be divided into three groups: the group of conservative, adaptive and innovative teachers.
\end{abstract}

Keywords: early childhood, curriculum, implementation

\section{A koragyermekkori nevelés curriculumának főbb jellemzői}

Az óvodai oktatásban 2019 szeptemberében egy új koncepciójú koragyermekkori curriculum lépett életbe, melynek 2019 decemberében a hivatalos kisebbségi magyar fordítása is megjelent. Az elmúlt 20 éves időszakban négy tantervet használtak a kisebbségi óvodai tanítási gyakorlatban: a 2000-től életbe lévő tantervnek 2006-ban jelent meg a kisebbségi oktatás számára készült hivatalos adaptációja, ezt váltotta a 2008-ban az EU-s elvek alapján átdolgozott tanterv, melyet 2019 őszén az elemi oktatás kompetenciaalapú tanterveinek sorába betagolódó kisgyermekkori curriculum váltott (Programa activităţilor instructiv-educative, 2000; Óvodai tanterv, 2006; Óvodai curriculum 2008; Koragyermekkori nevelés curriculuma, 2019). A 2019 öszén életbe lépett koragyermekkori nevelés curriculuma már a fogalomhasználatában is változást hozott, hisz óvodai oktatás helyett a koragyermekkori nevelésre fókuszál. Továbbá változást hozott a korcsoportot illetően, mivel nem csak a 3-6/7 éves korú gyermeket helyezi a középpontba, hanem a bölcsődés korú gyermeket is, négy alkorcsoportot meghatározva: 0-18 hónap, 19-36 hónap, 37-60 hónap, 61-72/84 hónap. Ebben a koncepcióban a bölcsődés kor is a közoktatási rendszer szerves részét képezi, ám a curriculum életbe lépett, de még nem történt meg a bölcsődék adminisztratív átkerülése az oktatási minisztérium hatáskörébe.

A koragyermekkori nevelés curriculuma a kompetencialapú, gyermekközpontú, cselekvéses tanulást középpontba állító elveket érvényesíti olyan magatartás- és viselkedésformák megszerzése érdekében, amelyek a kulcskompetenciák későbbi kialakulásának előfeltételei. A koragyermekkori nevelés esetében természetesen nem beszélhetünk a kompetenciák kialakulásáról/kialakításáról, ezt az időszakot 
valójában a kulcskompetenciák alapozási szakaszának tekinthetjük, a későbbi kompetenciák előfeltételeinek. Ezek a kulcskompetenciák kisiskoláskorban elemi szinten fejlődnek, V-X. osztály között érik el a funkcionális szintet, a kulcskompetenciák fejlett szintjéröl pedig a záró évfolyamokon, XI-XII osztályokban beszélhetünk (Koragyermekkori nevelés curriculuma, 2019, 13-14).

A koragyermekkori nevelés curriculumát a tantervkészítők a fejlődési területek, a fejlődési dimenziók és a viselkedésformák, mint a későbbi kompetenciák előfeltételeinek tengelye mentén építették fel, modellezték (Koragyermekkori nevelés curriculuma, 2019, 13-14). A kiindulópontot az óvodapedagógus számára a fejlődési területek képezik, melyeket a koragyermekkori nevelés curriculumában, illetve a Támpontok a gyermek korai tanulásához és fejlödéséhez születéstôl hét éves korig címü dokumentumban talál meg. Az oktató-nevelő munka tervezésekor a pedagógus a fejlődési területekböl kiindulva kiválasztja a fejlödés dimenzióit, majd ezekhez illeszti azokat viselkedésformákat a korcsoportok szerint, amelyeket szeretne előtérbe helyezni. A gyakorlatba ültetés során müveletesíti a kiválasztott viselkedésformákat a megfelelő tanulási tevékenységek megtervezésével (Koragyermekkori nevelés curriculuma, 2019, 14). A müveletesítés valójában magába foglalja a fejlődés dimenzióinak és viselkedésformáinak korcsoportonként történő kimunkálását, a megfelelő tartalom müveletesített formában való kidolgozását, a módszerek és eszközök müveleti felhasználását és alkalmazását, és csak végső soron a megvalósítandó feladatok müveletesítését.

A koragyermekkori nevelés curriculuma abban is változást hozott a korábbi curriculumhoz képest, hogy a tantervi elvárásokat a fejlődési területek szintjén fogalmazza meg, nem pedig a tapasztalati területek szintjén, ezáltal nagyobb szabadságot biztosítva az óvodapedagógus számára a tervezésben, ugyanakkor nagyobb szakmai felelősséget is helyezve a pedagógus vállára.

\section{A vizsgálat bemutatása}

Vizsgálatomban arra kérdésre kerestem a választ, hogy milyen a koragyermekkori nevelés curriculumának fogadtatása az óvodapedagógusok körében? Kérdőives lekérdezés módszerét alkalmaztam, 2020 október-november folyamán zajlott a lekérdezés online kérdőív formájában. A kérdőív főbb tömbjei: demográfiai kérdések, viszonyulás az új curriculumhoz és a változáshoz, a curriculum értelmezésének és implementációjának módozatai, a curriculum alkalmazhatósága a digitális oktatás keretei között (az utolsó kérdéstömböt jelen tanulmányban nem dolgozom fel).

118 pedagógus vett részt a vizsgálatban, akik átlagosan 15 évet töltöttek el az óvodapedagógusi pályán, két hónapja dolgozó pedagógustól 35 éve tevékenykedő pedagógusig. Az óvodapedagógusok legnagyobb többsége (tízből nyolc pedagógus) egyetemi végzettséggel rendelkezik, majdnem fele pedig I. didaktikai fokozattal. A megkérdezettek 55 százaléka városi intézményben dolgozik, szintén 55 százaléka ingázik a munkahelyére. A pedagógusok kétharmada napköziben dolgozik, és fele vegyes csoportot tanít.

\section{A curriculum megítélése és implementációja}

Az online kérdőíves lekérdezés eredményeit a következő fókuszpontok mentén mutatom be: asszociációk a curriculummal kapcsolatban, a tantervi váltás szükségessége, elégedettség és felkészültség a pedagógusok körében, a curriculum implementációjának módozatai, személyes viszonyulás a curriculummal szemben.

A pedagógusok számos asszociációt megfogalmaztak az új koragyermekkori nevelés curriculumához kapcsolódóan, mint azt az 1. ábrán láthatjuk. Leginkább a gyermekközpontúság és a kompetencia jelent meg a pedagógusok asszociációiban, továbbá a szabadság, a változás/újítás, a fejlődés és kísérlet. A komplexitás is megjelent, bár inkább a bonyolultság felé közelítve, továbbá a káosz és a hiányosság. 


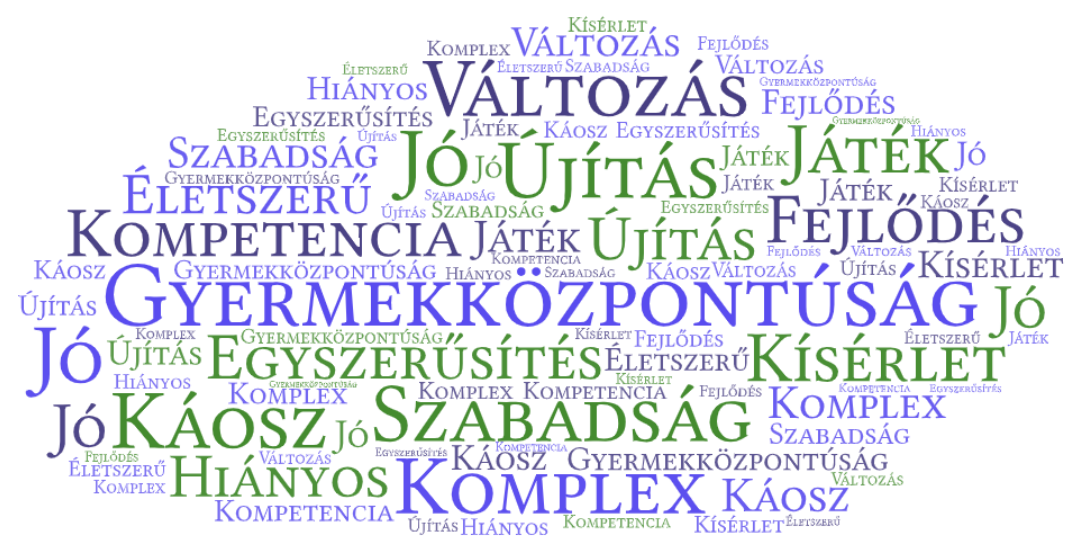

1. ábra: Curriculum asszociációk

A megkérdezett pedagógusok szerint a curriculum leginkább a kompetencia alapú oktatással hozott lényegi változást, a fejlődési területek - fejlődési dimenziók - viselkedésmutatók tengelyére való építéssel. „Eddig a témából bontottuk le a célt, most a kitüzött célt töltjük fel tartalommal. Ez az irányelv jobban tetszik." - vallja az egyik pedagógus. Továbbá nagyobb szabadságot biztosít mind a pedagógusok, mind a gyermekek számára, és többek szerint kiemelt szerepet kap benne a szabad játék. A pedagógusok egy másik csoportja az időkeretben látja a lényeges változást: a heti tevékenységszámok rugalmasságában, a napirendben. Egyesek a módszertani alkalmazásokban ragadják meg a változást (mesepercek, mozgáspercek, szabad levegö, opcionális), míg egy másik csoport nem lát lényegi változást, szerintük csak más fogalmi apparátus használatában merül ki a curriculum újítása.

A 2. ábra adatai szerint a tantervi váltáshoz elég pozitívan viszonyulnak a megkérdezett óvodapedagógusok:



2. ábra: Tantervi váltás (10 fokozatú Likert-skála)

A 2. ábra adatai szerint a megkérdezett óvodapedagógusok szükségesnek ítélték a változást a saját szemszögükböl $(m=7,36)$, kicsit kevésbé szükségesnek a kollégáik szemszögéböl $(m=6,28)$. Az ANOVA teszt szerint szignifikáns különbségek nem mutatkoznak a válaszokban a különböző változók (régiség, didaktikai fokozat, tanítási hely, ingázás, óvodatípus, óvodai csoport) mentén. A tantervi váltást nagy mértékűnek ítélték (69 százaléknyi változás), tízből hat pedagógus pont ilyennek képzelte el a tantervet, és ha neki kellene új tantervet kidolgoznia, hasonló koncepció alapján dolgozna. Akik 
mégis változtatnának, azok leginkább konkrétan meghatároznák a heti tevékenységszámokat, és konkretizálnák a fejlődési területek - fejlődési dimenziók - viselkedésmutatók tengelyét.

A 3. ábra szerint a megkérdezett óvodapedagógusok többsége elégedett az új curriculummal, annak alkalmazhatóságával a hétköznapi tanítási gyakorlatban $(\mathrm{m}=7,11)$, ám a pedagógusok úgy vélik, hogy kollégáik kevésbé elégedettek $(\mathrm{m}=6,42)$.

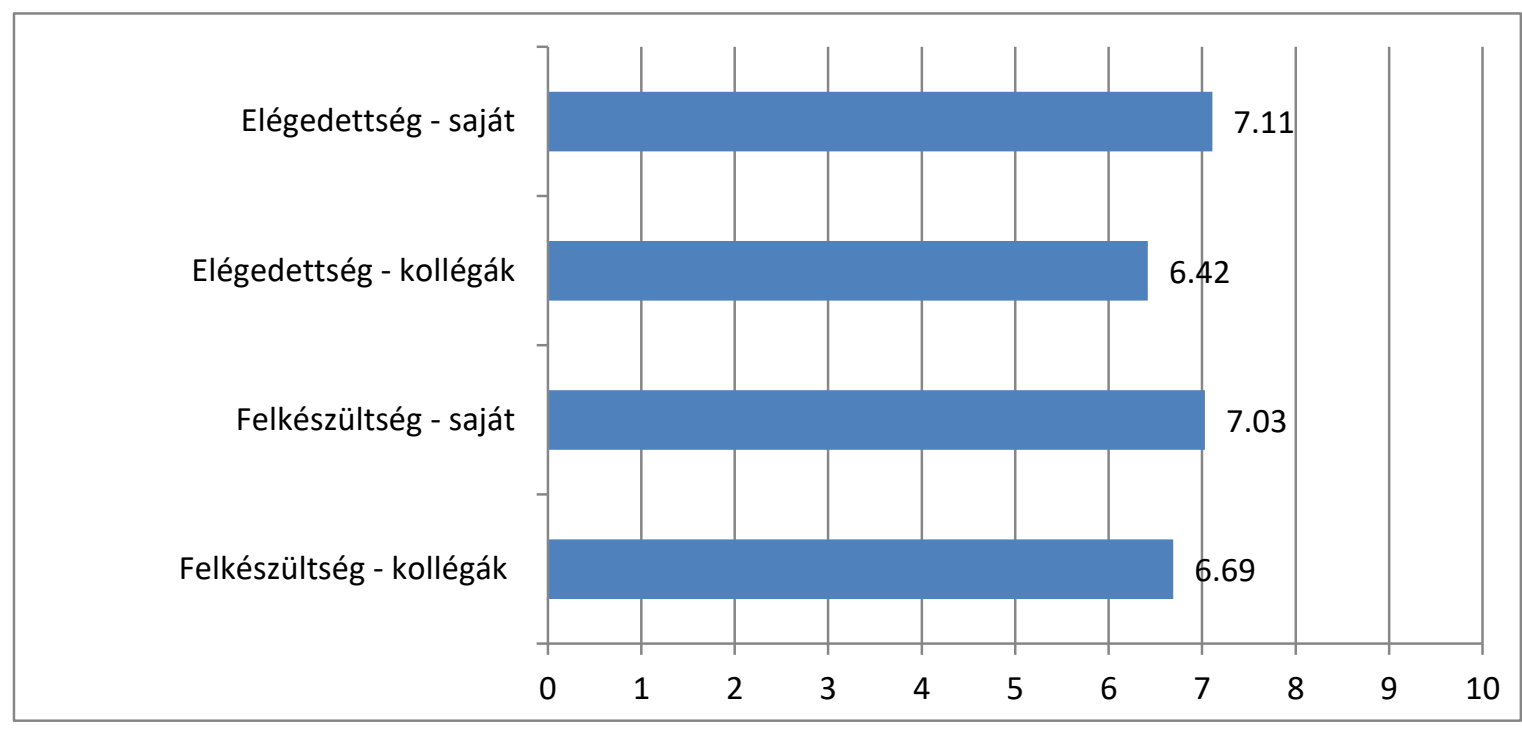

3. ábra: Elégedettség és felkészültség (10 fokozatú Likert-skála)

Az elégedettséget illetően a régiségnél tapasztaltam szignifikáns összefüggést: a 20 év fölötti régiséggel rendelkező pedagógusok jóval elégedettebbek a curriculummal, mint kollégáik. Az új curriculum gyakorlati alkalmazására való felkészültségüket jónak ítélik meg az óvodapedagógusok (70\% százalékos felkészültség), az ANOVA teszt alapján erősen szignifikáns összefüggést a didaktikai fokozat függvényében tapasztaltam: a felkészültség érzete arányosan növekedett a didaktikai fokozattal, azaz minél magasabb didaktikai fokozattal, vagyis nagyobb szakmai tapasztalattal rendelkezik a pedagógus, annál felkészülttebbnek érzi magát szakmailag a tanterv alkalmazására.

Az óvodapedagógusok különböző módon láttak neki a deklarált curriculum értelmezésének, megismerésének:

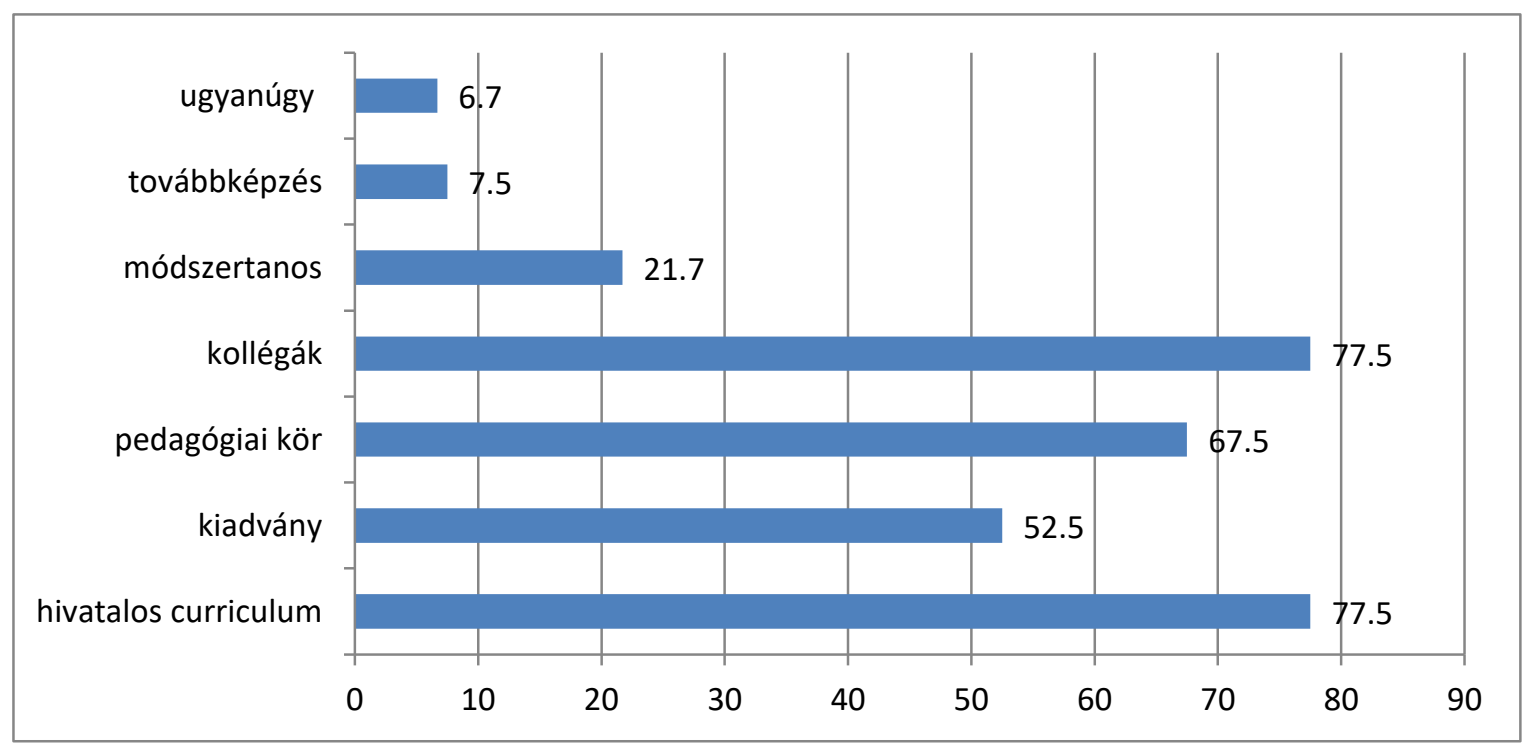

4. ábra: A curriculum megismerése (\%) 
A 4. ábra szerint az óvodapedagógusok 77,5 százaléka autonóm tanulás révén, a hivatalos tantervi dokumentum alapos tanulmányozásával kezdte az új curriculum megismerését, illetve a kollégákkal folytatott eszmecserék révén próbálta értelmezni magának a curriculumot. Az év eleji pedagógiai körök is segítettek a curriculum begyökereztetésében (67,5\%), illetve a pedagógusok fele szakmai kiadványokat tanulmányozva próbálta behatóbban megismerni az új curriculumot. A szakmai kiadványokat illetően a megkérdezettek fele nem fért hozzá aktuális kiadványokhoz, aki pedig hozzáfért, csak román nyelven. A 4. ábrán aggodalomra ad okot, hogy mindössze a megkérdezettek 7,5 százaléka vett részt ilyen tematikájú továbbképzésen, ahol szakemberek segítségével ismerhették volna meg a curriculumot.

1. táblázat: Curriculumhoz való viszonyulás (5 fokozatú Likert-skála)

\begin{tabular}{|l|l|}
\hline Kijelentés (1-5 fokozatú skála) & Átlag \\
\hline 1. Szívesebben dolgozom az új curriculum alapján. & $3,50^{*}$ \\
\hline 2. Nem látom még át teljesen az új curriculum koncepcióját. & 2,60 \\
\hline $\begin{array}{l}\text { 3. Az óvodapedagógusok többsége alkalmazza az új curriculumot, de nem látja még } \\
\text { át ténylegesen a koncepcióját. }\end{array}$ & $3,34^{*}$ \\
\hline 4. Felkészültnek érzem magam az új curriculum alkalmazására. & 3,18 \\
\hline $\begin{array}{l}\text { 5. Kollégáim többsége felkészültnek érzi magát a munkaterv megírására az új } \\
\text { curriculum tükrében. }\end{array}$ & 3,06 \\
\hline 6. Számos ötletem van a curriculum még hatékonyabbá tételére. & 2,33 \\
\hline
\end{tabular}

Az 1. táblázat adatai szerint a megkérdezett óvodapedagógusok viszonylag szívesen dolgoznak az új curriculum alapján $(m=3,50)$, és felkészültnek is érzik magukat a megváltozott tervezési dokumentumok elkészítésére. Az ANOVA teszt szignifikáns összefüggést mutatott az óvodatípus esetében, a napközis óvodapedagógusok pozitívabb hozzáállást tanúsítanak. A didaktikai fokozat is szignifikáns összefüggést mutatott, a magasabb fokozattal rendelkezők tanúsítanak pozitívabb attitüdöt a curriculummal szemben.

Faktorelemzéssel pedagógusi csoportokat alakítottam ki: a konzervatív, az alkalmazkodó és az újító pedagógusok csoportját. A konzervatív pedagógusok szükségtelennek látják a tantervi váltást, elégedetlenek az új curriculummal, negatív attitüdöt tanúsítanak, és inkább csak a fogalmi apparátus változásában látják az új curriculum lényegét. Az alkalmazkodó pedagógusok kiemelten szükségesnek látták a váltást, elégedettek is a curriculummal, pozitív attitüdöt tanúsítanak, de nincsenek újító ötleteik. Az újító pedagógusok szintén pozitív attitüdöt tanúsítanak a tanterv és a változás iránt, de csak kisebb mértékben elégedettek, számos hatékonyabbá tevő ötletük van, és szívesen bekapcsolódnának tantervfejlesztő munkába.

\section{4. Összegzés}

A vizsgálat alapján megállapítható, hogy az óvodapedagógusok többsége pozitívan fogadta az új koragyermekkori nevelés curriculumát. Kiemelten értékelik a szabadságot, amit a curriculum biztosít a pedagógus, illetve a gyermek számára. $\mathrm{Az}$ óvodapedagógusok viszonylag elégedettek a koragyermekkori nevelés curriculumával, és eléggé felkészültnek is ítélik saját magukat és kollégáikat a curriculum gyakorlati alkalmazására. A deklarált curriculum értelmezése és megvalósítása szinte teljesen a pedagógusra maradt, a pedagógiai körökön kívül az autonóm tanulás és a kollégákkal folytatott szakmai beszélgetések képezték a curriculum implementációjának eszközeit, a továbbképző tanfolyamok és magyar nyelvű szakmai kiadványok kevésbé voltak hozzáférhetőek a pedagógusok számára. A tantervi váltáshoz eltérő módon viszonyulnak a megkérdezett pedagógusok, a konzervatívabb réteg ellenzi a váltást, az alkalmazkodó réteg gyorsan adaptálódik az újításhoz, míg egy szükebb, újító réteg folytatná a megkezdett tantervi váltást, továbbfejlesztve a curriculumot. 


\section{Irodalomjegyzék}

***2000. Programa activităţilor instructiv-educative în grădiniţa de copii. Editura V\&I Integral, Bucureşti

***2006. Óvodai nevelési-oktatási tevékenységek tanterve magyar tannyelvü óvodák számára. Programa activităţilor instructiv-educative în grădiniţa de copii, pentru grădiniţele cu predare în limba maghiară. Ministerul Educaţiei şi Cercetării, Bucureşti. http://www.edu.ro/index.php/articles/6730

***2007. Reperele fundamentale privind învăţarea şi dezvoltarea timpurie a copilului între naştere şi 7 ani. Támpontok a gyermek korai tanulásához és fejlödéséhez születéstöl hét éves korig. Reprezentanţa UNICEF România.

***2008. Óvodai tanterv. Curriculum pentru învăţământul preşcolar (3/7 ani). Ministerul Educaţiei, Cercetării şi Tineretului, Bucureşti.

***2019: A koragyermekkori nevelés curriculuma. Ministerul Educației și Cercetării, București.

***2019. Curriculum pentru educație timpurie (a copiilor de la naștere până la vărsta de 6 ani). Minis-

terul Educaţiei Naţionale, Bucureşti. URL:

https://www.edu.ro/sites/default/files/Curriculum\%20ET_2019_aug.pdf

\section{Szerző:}

Stark Gabriella, Partium Christian University, Oradea; Babeş-Bolyai University, Satu Mare, (Romania) E-mail: ngabriella77@gmail.com. 